\title{
Boundaryless Careers in a Large Brazilian Financial Institution
}

\author{
Thais Carazato Pisapia \\ Escola de Administração de Empresas de São Paulo da Fundação Getúlio Vargas, \\ São Paulo, SP, Brazil \\ Thomaz Wood Jr. \\ Escola de Administração de Empresas, da Fundação Getúlio Vargas, São Paulo, SP, Brazil \\ Pedro F. Bendassolli ${ }^{1}$ \\ Departamento de Psicologia da Universidade Federal do Rio Grande do Norte, \\ Natal, RN, Brazil
}

\begin{abstract}
In recent years, changes in business and work organization led to the emergence of new career models. Among these models, the boundaryless career, which is premised on high professional mobility, has gained prominence. However, there are few empirical studies on this phenomenon in Brazil. The present study seeks to address this gap. The objective of this study is to identify the attitudes of individuals towards their careers in a large Brazilian financial institution. Methodologically, the study uses a mixed design. The quantitative entailed the application of the Boundaryless Career Attitudes Scale, which was previously validated for use in the Portuguese language. The scale was administered to 126 professionals working in seven areas of the above-referenced organization. The qualitative study involved 11 indepth interviews with professionals who are identified using the respondent list from the quantitative portion of the study. The results indicate a strong presence of boundaryless career attitudes within the organization, although there are differences among individuals (which stem from differences in the individuals' tenures at the organization) and differences among areas of the organization. The article seeks to explain the reasons for these differences and to discuss the apparent paradox between an evident boundaryless career attitude and a strong desire for permanence and bonding with the organization. The present study contributes to knowledge in the field of career studies in Brazil because it uses a validated scale of attitudes and reveals the reality of a large local organization.
\end{abstract}

Keywords: Professional careers in Brazil, new career models, boundaryless career, professional mobility, financial institution.

\section{Carreiras Sem Fronteiras em uma Instituição Financeira Brasileira de Grande Porte}

\section{Resumo}

Nos últimos anos, mudanças nas empresas e na organização do trabalho levaram ao surgimento de novos modelos de carreiras. Entre tais modelos, ganhou proeminência o modelo de carreiras sem fronteiras, que tem como premissa uma alta mobilidade profissional. No Brasil, entretanto, ainda há poucos estudos empíricos sobre o fenômeno. Esta pesquisa procurou endereçar esta lacuna. O objetivo deste tra-

\footnotetext{
Mailing address: Rua Vicente Mesquita, 885, Apto. 501, Natal, RN, Brazil 59063-650. Phone: (84) 3025-3040. E-mail: thais_pisapia@yahoo.com.br, thomaz.wood@fgv.br and pbendassolli@gmail.com
} 
balho foi identificar as atitudes dos indivíduos frente à carreira em uma instituição financeira brasileira de grande porte. Metodologicamente, o estudo utilizou um desenho misto. A parte quantitativa consistiu na aplicação da Boundaryless Career Attitudes Scale, previamente validada para utilização em língua portuguesa. A escala foi aplicada a 126 profissionais de sete áreas da referida organização. A parte qualitativa envolveu a realização de 11 entrevistas em profundidade com profissionais identificados da base de respondentes da parte quantitativa. Os resultados indicam forte presença de atitudes de carreira sem fronteiras dentro da organização, embora haja diferenças entre áreas e entre indivíduos, fruto de seu tempo de trabalho na organização. O artigo procura explicar as razões para estas diferenças e discute o aparente paradoxo entre uma elevada atitude para carreira sem fronteiras e a constatação de um forte desejo de permanência e vínculo com a organização. $O$ trabalho contribui para a construção do conhecimento no campo de estudos de carreiras no Brasil, à medida que utiliza uma escala validada de atitudes e revela a realidade de uma grande organização local.

Palavras-chave: Carreiras profissionais no Brasil, novos modelos de carreira, carreira sem fronteiras, mobilidade profissional, instituição financeira.

\section{Carreras Sin Fronteras en una Gran Institución Financiera Brasileña}

\section{Resumen}

En los últimos años, los cambios en los negocios y en la organización del trabajo llevado a la aparición de nuevos modelos de carrera. Entre estos modelos, el modelo carreras sin fronteras ha ganado prominencia. Esto modelo se basa en una alta movilidad. En Brasil, sin embargo, existen pocos estudios empíricos sobre el fenómeno. Esta investigación busca llenar este vacío. El objetivo de este estudio fue identificar las actitudes de los individuos a la carrera dentro de una grande institución financiera de Brasil. Metodológicamente, el diseño del estudio se utilizó una mezcla cuantitativa y cualitativa. La parte cuantitativa fue la aplicación de la Boundaryless Career Attitudes Scale, previamente validado para su uso en portugués. La escala se administró a 126 profesionales en siete áreas de la organización. La parte cualitativa implicó la realización de 11 entrevistas con profesionales de la base de la parte cuantitativa. Los resultados indican una fuerte presencia de las actitudes de carrera sin fronteras dentro de la organización, aunque hay diferencias entre áreas y entre los individuos, el resultado de su tiempo trabajando en la organización. El artículo trata de explicar las razones de estas diferencias y se analiza la aparente paradoja entre una actitud hacia la carrera sin fronteras y un fuerte deseo de permanecer en la organización. El trabajo contribuye a la construcción del conocimiento en el campo de los estudios de la carrera en Brasil, ya que utiliza una escala validada de las actitudes y revela la realidad de una organización local.

Palabras clave: Carreras en Brasil, nuevos modelos de la carrera, carrera sin fronteras, movilidad profesional, institución financiera.

The word career, meaning craft or profession with ascending steps, was born as a result of the emergence of an industrial society and has over time implicitly come to refer to a professional or life trajectory (Chanlat, 1995; Dubar \& Tripier, 2005; Inkson, 2007). According to London and Bray (1984), careers are characterized by the various positions held and types of work performed during the professional life of an individual. A career refers to the work experience of a person and has both objective and subjective aspects (Arthur, Hall, \& Lawrence, 1989).

On one side, there are the individual's motives and aspirations, and on the other side, there are the constraints and requirements imposed by the organization and society. For an indi- 
vidual, a career follows the evolution of professional experience, whereas for an organization, it involves the establishment of guidelines, processes and decisions related to the functions, positions, compensation and movement of professionals. In the literature, this dual nature of the career is driven by vocational psychology and career guidance traditions on the one hand and by managerial traditions on the other hand (Gunz \& Peiperl, 2007).

By the beginning of this century, the career study field had spawned several lines of debates and controversies, some of which are associated with the dual nature of a career, which is both social and personal. For example, Peiperl and Arthur (2000) highlight four discussion foci in this area: (a) the dichotomy between agency and structure, which considers whether careers are the product of individual actions or institutional constraints; (b) the dichotomy between stability and change, which refers to whether the career world is relatively invariant over time or subject to continuous changes; (c) the dichotomy between universalism and particularism, which considers assumptions and descriptions relating to human nature, as well as concepts and terms used to describe careers in various contexts and cultures; and (d) the dichotomy between institutional knowledge and individual knowledge, which is similar to the debate regarding qualifications (which are more collective and institutionalized) and competencies (which are more flexible and belong to the individual, allowing the individual to transfer competencies from one position/organization to another; Inkson \& Parker, 2005).

Although these four lines of theory have been debated for more than a decade, they continue to be relevant to the subject of careers. For example, the present time (in particular, the period beginning in the early 1990s in Brazil), which is marked by new arrangements and employment contracts, is often contrasted with a previous period in which jobs were more stable and the perceptions of career growth and development were more linear (e.g., Dutra, 2009; Kilimnik, 2011). The final quarter of the twentieth century was marked by privatizations, mergers, acquisitions, restructurings, outsourcing and staff reductions. These changes have brought new challenges and opportunities for professionals. In particular, although the changes have facilitated mobility within and between companies, they have simultaneously reduced job security and led to changes in the relationship between the individual and the organization (Grzeda, 1999; Rousseau, 1995).

In this scenario, a new concept of career has emerged, one that is based on a greater appreciation of the professional's individual responsibility (Fontenelle, 2007; Stickland, 1996). Thus, the concept of employment based on stability and clearly defined working positions has gradually given way to an emphasis on the continuous adaptation of the individual to a rapidly changing environment (Beck, 2000). In response to changes in the forms of work institutionalization, the career literature has been transformed. Specifically, the previous focus on organizational careers (Hall, 1976; Van Maanen, 1977) has shifted to new models and career arrangements, which are described by some authors as emerging, or non-traditional, career models (Bendassolli, 2009; Sullivan, 1999).

The new models seek to adjust the theories on careers in light of the demographic, economic, labor, social, organizational and technological changes that have affected the classic conception of careers, which was based on routines, processes, regulatory systems and institutional structures that were more stable than those that exist today (Inkson, 2007).

Among the new career models, we can highlight the protean career (Hall 1976, 2002, 2004); the boundaryless career (Arthur, 1994; Arthur, Inkson, \& Pringle, 1999; Arthur \& Rousseau, 1996); the portfolio career (Baruch, 2004, 2006; Borgen, Amundson, \& Reuter, 2004; Inkson \& Baruch, 2009; Templer \& Cawsey, 1999); and the narrative career (McMahon \& Patton, 2006; Savickas, 2009). Among the enumerated models, the boundaryless career mod$\mathrm{el}$ is the focus of the present study. A boundaryless career is defined by Arthur and Rousseau (1996) as ". . . the opposite of 'organizational careers' - careers conceived to unfold in a single employment setting" (p. 5). T he best known characteristic of this model is mobility, 
which refers to the passage of the professional through several areas within an organization and through a number of organizations. The model also includes other relevant characteristics. For example, Arthur and Rousseau cite the possibility of autonomous working conditions; the use by individuals of external relationship networks; the transition from technical functions to managerial functions; the reduction of time spent at work in favor of spending more time with family or engaging in other activities; and the individual's perception of a professional trajectory without structural obstacles.

As defined by Arthur and Rousseau (1996), the boundaryless career stands in stark contrast to the concept of the organizational career. Whereas the latter is developed through the professional advancement of an individual within a formal organizational hierarchy, the boundaryless career unfolds in a temporal sequence of work experiences that is not limited by the boundaries of a single organization, occupation or even country. Thus, the verticality of the traditional model, in which the individual often devotes his professional life to a single company, is replaced by the transversality of the boundaryless career (Bendassolli, 2009).

An essential aspect of the boundaryless careers model is the associated competencies. Every career can be understood as the trajectory of the individual's work experiences, through which he acquires various types of knowledge. The sequence of knowledge creation establishes or shapes the career (Mendenhall, Kuhlmann, \& Stahl, 2001). According to DeFillippi and Arthur (1994), the individual must develop three sets of core competencies to construct his career (note that although these authors discuss competencies in the context of the boundaryless career model, competencies are also present in discussions of other career models): know-why, know-how and know-whom.

As explained by DeFillippi and Arthur (1994), know-why competencies refer to the motivations for conducting an activity; that is, the personal meaning of and identification with the work. Know-how competencies comprise the competencies and knowledge necessary for the proper performance of the work; in this regard, competencies that can be "carried" from one context to another are especially relevant. Finally, know-whom competencies refer to relationship networks developed during one's professional life. Know-whom competencies focus on social capital, which generates communication, influence and solidarity between people who are in contact or live with each other.

Since its proposal in the late 1990s, the boundaryless career model has given rise to several theoretical and empirical studies (for an overview of these studies, see Tams \& Arthur, 2010). For example, in the international literature, there is research on the relationship between gender and mobility (Forret, Sullivan, \& Mainiero, 2010); relationships among certain sectors (such as technology); the viability of the boundaryless career model (Inkson \& Parker, 2005); and competencies and career (Colakoglu, 2011; Eby, Butts, \& Lockwood, 2003). Studies on competencies and career indicate that higher levels of the above-mentioned competency sets (know-why, know-how and know-whom) are associated with higher levels of perceived success. However, studies that question the scope or even the practical feasibility of the concept of boundaryless careers can also be found. For example, Currie, Tempest and Starkey (2006) argue that although this model may be suitable for more skilled and younger workers, it might be inappropriate for older workers who possess more general qualifications. Similar results are presented by Pringle and Mallon (2003), whose research indicates potential limits of the boundaryless career model when considering individuals belonging to certain ethnic groups and collective cultures.

In Brazil, studies of new career models have intensified since the beginning of the 2000s (Balassiano, 2006; Dutra, 2009). Moreover, these studies not only investigate new career models (Bendassolli \& Wood, 2010; Dutra, 2009; Kilimnik, 2011; Kilimnik, Sant'Anna, \& Castilho, 2007; Lacombe, 2005; Scalabrin, 2008) but also address a variety of other topics, such as the relationships among organizational commitment, identification with one's work and career 
success (Bastos \& Andrade, 2002); career selfmanagement (Fontenelle, 2007); and the subject of this article, the presence of the boundaryless career concept in the financial sector.

For example, Veloso and Dutra (2011) studied professionals employed by the former São Paulo state bank, Banespa, which was privatized in 2000. They show that regardless of the professionals' decisions whether to stay or to leave the organization (by voluntary resignation), the manner in which they manage their careers determines how they handle their professional transitions. Thus, the authors suggest that boundaryless careers are not necessarily related to physical mobility but rather can be developed even in the context of a stable job if the professional's attitude is consistent with a boundaryless career (psychological mobility). The study by Oltramari and Lorenzato (2012) emphasizes the tensions and dilemmas involved in the construction of a boundaryless career by bank managers; in particular, the pressure from the organization to develop physical mobility attitudes and, more importantly, psychological attitudes, and the difficulty of reconciling these pressures with family life.

Given the need to expand the national literature on contemporary careers and the importance of exploring its manifestation in different segments, we present this study, which aims to investigate the presence of boundaryless career related attitudes in a large financial institution. The choice of this industry is due to, among other reasons, the fact that this sector allows one to simultaneously consider a confluence of multiple careers (ranging from technology and information management to more operational activities); it is characterized by intense concentration and organizational verticalization (in Brazil today, the bank industry is characterized by the concentration of few large organizations); and it espouses a managerial ideology that accords with the characteristics of boundaryless careers, which include physical mobility, expatriations and management policies that emphasize individual responsibility for professional growth and performance (Oltramari \& Lorenzato, 2012).
Additionally, certain studies have questioned whether boundaryless career attitudes are widely shared constructs that exist regardless of culture and context. For example, Gerber, Wittekind, Grote, Conway and Guest (2009) show that despite the discourse, the generalization of career guidance is not supported cross-culturally. These authors even cite studies in which they detect preferences for "traditional" careers, which are synonymous with stability and security. Thus, in the context of a large Brazilian private banking organization, wherein there are strong incentives for professional development and advantageous compensation programs, would professionals nonetheless prefer boundaryless careers? If so, how can this preference be reconciled with the quasi-stable employment of these professionals, considering (as will be described later) their long tenures at the bank? Is there be any relationship between a boundaryless career attitude and variables such as organizational area, position, professional training and number of transitions within the organization throughout the individual's career?

To answer these questions, the present study adopts the framework of the boundaryless career model. The study employs a mixed methodology that is based on the investigation of quantitative relationships among variables and a deeper qualitative analysis accomplished through interviews. The adopted methods are presented in the following section.

\section{Methods}

\section{Participants}

The study was conducted with professionals employed by one of the largest private financial institutions in Brazil. The institution has a traditional organizational structure, well-defined processes, rigid work schedules and clear limits of authority that are determined in accordance with an individual's position and function. Just prior to the performance of this research, a new, formal model of staff performance evaluations based on the competencies and achievement of goals and objectives and aimed at guiding career decisions - was deployed. 
Table 1

Surveyed Areas

\begin{tabular}{ccc}
\hline Number & of \\
employees & Description & Characteristics \\
\hline
\end{tabular}

$\begin{array}{lll}\begin{array}{l}\text { Individual } \\ \text { customer } \\ \text { service }\end{array} & 3,000 & \begin{array}{l}\text { Call centers for bank customers and } \\ \text { branch managers }\end{array} \\ \begin{array}{l}\text { Individual } \\ \text { commercial }\end{array} & 40,000 & \begin{array}{l}\text { Branches that rely on the bank's com- } \\ \text { mercial staff and are responsible for } \\ \text { direct customer contact }\end{array} \\ \begin{array}{l}\text { Individual } \\ \text { credit and } \\ \text { collections }\end{array} & 400 & \begin{array}{l}\text { Dedicated to the definition and opera- } \\ \text { tionalization of lending and arrears } \\ \text { recovery strategies }\end{array}\end{array}$

Manages the bank's legal issues. The Legal 1,200 area is responsible for guiding the business units in accordance with the banking laws

Develops and updates the statistical models used by the business units and manages the consolidated risk position of the bank

Manages processes related to the personnel management cycle (e.g.,

Human resources

1,500 selection, hiring, career management, compensation, performance evaluations, development)

Responsible for development and maintenance of all information systems and the corresponding infrastructure
High standardization level, rigid division of labor, focus on efficiency and high control amplitude

High standardization level and hierarchy; limited autonomy; separation between planning and execution

High standardization level in credit committees and collection centers; high degree of informality and autonomy in credit policy and collection teams

Includes support departments with standardized processes; lawyers representing the bank in court act with greater autonomy and flexibility

High degree of flexibility and low degree of discipline and control; planning and execution activities conducted by the same teams

High degree of standardization and routinization of tasks; planning and execution activities conducted by different teams

Broad autonomy; low ranking; planning and execution activities conducted by the same teams
The quantitative stage of this research involved the participation of 126 professionals from seven different areas (see Table 1). In the period during which the quantitative research was conducted, all participants occupied middle and senior management positions, including coordinator $(29 \%)$, manager $(43 \%)$, superintendent $(25 \%)$ and director $(3 \%)$. Regarding the demographic profile, $85 \%$ of the respondents were between 31 and 50 years old, 71\% had completed graduate school, and $18 \%$ had completed a master's degree. Most professionals $(82 \%)$ were married, and $68 \%$ had children. Regarding tenure, $25 \%$ of the participants had worked at the bank for more than 20 years; $9 \%$ had been there between 15 and 20 years; 53\% had worked at the bank between 5 and 15 years; and $13 \%$ had been employed by the organization 5 years or less. Therefore, the sample generally comprised experienced professionals who were already socialized in the organization's culture.

The qualitative stage involved the participation of 11 professionals who had responded to the questionnaire administered during the quantitative step. Although we attempted to maintain a similar sample profile, the qualitative sample was one of convenience. Participants were distributed as follows: two were from the 
modeling and risks area (a male mathematician between 25 and 30 years of age and a female economist between 40 and 45 years of age); two were from the legal area (two lawyers, one man and one woman, both between 35 and 40 years of age); two were from the individual credit and collections area (two male engineers, both between 30 and 45 years of age); two were from the technology area (two engineers, one man and one woman, both aged between 30 and 35 years); one was from the individual customer service area (a male engineer aged between 30 and 35 years); one was from the individual commercial area (a man aged between 30 and 35 years); and one was from human resources (a woman between 30 and 35 years of age with a degree in advertising and marketing).

\section{Instruments and Procedures}

The first stage of the research used a threepart questionnaire. The first part of the questionnaire comprised a survey of demographic information; the second part included questions about the career of the interviewee; and the third part was dedicated to the survey on boundaryless career attitudes. The third part of the questionnaire was based on the Boundaryless Career Attitudes Scale (BCAS) developed by Briscoe, Hall and DeMuth (2006), which was adapted and validated for the Portuguese language by Oliveira et al. (2010) and called Escala de Atitudes de Carreira Sem-Fronteiras (EACSF).

The original version of the BCAS has 13 items divided into two subscales, both of which aim to assess boundaryless career attitudes. The first subscale, called Psychological Mobility (PSM), comprises eight items and assesses the individual's perception of his ability to make career transitions. The second subscale, called Physical Mobility (PHM), contains five items that evaluate the intensity of the individual's interest in remaining at the same organization or, in other words, the perception of the ability to perform border transitions. The authors of the Brazilian version of the BCAS retained ten items, six in the PHM subscale and four in the PSM subscale (Oliveira et al., 2010). Good reliability indices were obtained for the global scale (alpha $=.76)$ and for the PHM (alpha $=.79)$ and PSM (alpha $=.87)$ subscales.

Each of the 10 items was evaluated based on a Likert scale ranging from 1 ("does not describe me") to 5 ("describes me completely"). The questionnaire was administered over the Internet using the SurveyMonkey tool. The anonymity and confidentiality of the responses were preserved by the researchers.

The second stage of the research involved conducting semi-structured interviews aimed at deepening the understanding of the issues identified in step one. The interview script contained questions related to the career of the interviewee, including the following topics: (a) activities performed by the interviewee (to contextualize his work); (b) the individual's perception of the competencies necessary to perform his work and to advance his career (i.e., an exploration of know-why, know-how and know-whom competencies; based on DeFillippi \& Arthur, 1994); and (c) questions about the meaning of the interviewee's work and his career satisfaction (based on Lips-Wiersma \& Mcmorland, 2006). Interviews began with a brief explanation of the purpose of the research and an assurance that the confidentiality of the information would be maintained. In addition, authorization to record and subsequently transcribe and analyze the responses was requested. At the end of the interview, the respondent was encouraged to provide additional comments deemed relevant to the theme.

The research was conducted with the consent of the organization. In accordance with Resolution 196/96 of the National Health Council (1996), all ethical procedures applicable to research involving human beings were followed, including anonymity, the freedom to leave the research at any time, guaranteed confidentiality and the collective processing of information (i.e., the responses of each interviewee were not considered separately; rather, all responses were considered collectively).

\section{Data Analysis Procedures}

Analysis of the data obtained through the administration of the EACSF was conducted in 
accordance with the instructions provided in the studies by Briscoe et al. (2006) and Oliveira et al. (2010). The first step was to assess the EACSF psychometric characteristics of the sample used in this study. Thus, a descriptive inspection of the database was conducted to determine whether the data matrix was factorable, and factorability was confirmed by a significant Bartlett's test, $X 2(45)=442,947, p<.001$.

A moderate Kaiser-Meyer-Olkin (KMO) index of .74 was obtained - which is nearly equivalent to the index (.79) found in the pilot study by Oliveira et al. (2010) - indicating that the sample was appropriate. After the factorial structure was established and the internal consistency was ensured (as assessed by Cronbach's alpha), the next step was to investigate the associations between the EACSF factors and the other variables introduced in the study. This investigation was accomplished using techniques for comparing means (ANOVA) and correlation (Pearson correlation test).

The information obtained from the interviews (qualitative data) was examined using thematic content analysis (Bardin, 1977). After the interviews were transcribed, their content was organized according to the pre-analytical dimensions adopted in this study (in accordance with the theoretical framework) and present in the interview script. In addition, common themes among the interviews were identified and compared with each other.

\section{Results}

\section{Presentation of Quantitative Data}

First, the results of the factor analysis conducted with the data obtained through the administration of the EACSF are reported. As recommended by the authors of the original scale (Briscoe et al., 2006) and by the authors of the version translated and adapted to Portuguese (Oliveira et al., 2010), two factors were required, using principal components analysis (PCA), oblique rotation (oblimin), a criterion of factor loading higher than .40 for retention of items, and $p<.05$.
As evidenced by the information presented in Table 2, the EACSF retained its two original factors (and the ten items included in these factors) with this sample of professionals in the financial sector. All factor weights are above the established cutoff point $|\lambda>.40|$. In total, the two factors explain $55.41 \%$ of the data variance and have moderate to good internal consistency indices (Cronbach's alpha) in the subscales $(\mathrm{PHM}=.85 ; \mathrm{PSM}=.74)$ and in the global scale $($ alpha $=.74)$. Factor averages were moderately high: 3.89 for PHM and 3.03 for PSM. These averages indicate that the professionals in this study generally tend to prefer work activities that allow them to have contact with other people, contexts and organizations. The averages also suggest that participants actively seek work opportunities that allow them to achieve their goals and mobility preferences.

Once the factor analysis was conducted and the psychometric consistency of the original instrument structure with the current sample was ensured, two analyses were conducted. One analysis compared the means of the two factors (ANOVA with Tukey's post-hoc test) with the variables relating to the participants' area of operations, positions and training. The other analysis considered the correlation (Pearson correlation) between the two factors and the variables for the number of transfers between areas within the organization and for the number of voluntary employment shifts during respondents' careers. Any significant differences are reported under $p<.05$.

The comparison of means (ANOVA) identified significant relationships between the PHM and area of operation, though with very little effect size $\left(F_{[6,119]}=2.74 ; p<.01 ; \omega=.07\right)$. Professionals in the commercial area present significantly higher means in this factor compared to professionals in the credit and collections area $(\Delta \mathrm{M}=.59)$, and professionals in the technology area also have higher means compared to professionals in the credit and collections area $(\Delta \mathrm{M}=.57)$. Significant differences between areas of operation were also evidenced for PSM but with modest effect size $\left(F_{[6,119]}=3.84 ; p<\right.$ 
Table 2

Loading Factor of Items of the BCAS, Reliability Indices and Factor Average

Factors

Items

PHM PSM

1. I like activities that require me to work outside the organization.

2. I like activities that require me to work outside of my own department.

3. I like working with people outside my organization (such as customers, suppliers, partners, regulators).

4. I like jobs that require me to interact with people in numerous different organizations.

5. In the past, I looked for opportunities that would allow me to work outside the organization in the future.

6. I feel refreshed by new experiences and situations

7. I would feel very disoriented if I could not work for the organization in which I currently work.

8. I prefer to stay in an organization with which I am familiar rather than seeking opportunities in other workplaces.

9. If the organization in which I work offered jobs guaranteed to last a lifetime, I would never work for another organization.

10. My ideal career would develop within a single organization.

Explained variance

Average (general: $3.65 ; S D=.77$ )

Standard deviation

Note . Physical Mobility $=$ PHM, Psychological Mobility $=$ PSM. The items that comprise the PHM factor were reversed for analysis. The averages of this factor refer to the preference or attitude change towards the current organization.

$.01 ; \omega=.12)$. Specifically, professionals in the technology area had significantly higher means for this factor compared with professionals in the credit and collections area $(\Delta \mathrm{M}=.81)$ and in the human resources area $(\Delta \mathrm{M}=.82)$.

The only other significant association observed between a factor of boundaryless career attitudes and a study variable occurred between the variable for duration of employment by the organization and PHM $(r=-.32 ; p<.01$ - twotailed). It can thus be deduced that as the tenure of the professional with the organization decreases, the more prone he is to employment shifts (negative correlation).

\section{Presentation of Qualitative Data}

In this subsection, the thematic categories identified by content analysis are presented. The purpose of this step was to understand participants' working context, their experiences related to the core competencies of the boundaryless career and their views regarding their role in their own career development.

Know-Why Competencies. As explained above, know-why competencies refer to the motivations for conducting a particular activity. The fact that managers perform a job with meaning is relevant to the development of know-why competencies (Lacombe, 2005). In turn, these 
competencies reveal the motives, interests and expectations of managers regarding their careers and the level of their identification with the work and with the organization.

Nearly all respondents showed great interest in work challenges and the expansion of their knowledge. They declared a preference for being in a challenging environment characterized by the constant introduction of new projects that require different skills and allow respondents to develop professionally. Routine and monotonous activities are not considered learning opportunities. According to one respondent:

Challenges are really nice, and the feeling when we successfully overcome them is great. In addition, the dynamics of the banking business are quite interesting because they do not allow the work to be stable and monotonous. Your work is not strictly limited to the legal aspects of the business; rather, you have a relationship with many different areas and need to learn about the financial part of the organization, leadership, and people management. Learning is very motivating for me. (Legal manager)

Respondents also indicated that the management of people was a topic of interest. Team leadership can provide a professional with status and power. In addition, the manager may achieve fulfillment through the development of other individuals. According to one respondent:

"I realized that my dream, my career goal, is to consolidate as a leader, a manager, regardless of the activity that I perform. Today, leading increasingly larger groups is a motivation and a goal for me" (Credit and collections superintendent).

Thus, the know-why competencies mentioned by respondents suggest a proximity to the characteristics of boundaryless careers. Motivations associated with the characteristics of a traditional career, such as stability or safety, were not mentioned by respondents.

Know-How Competencies. Know-how competencies include the skills and knowledge necessary for the proper performance of one's work. To develop know-how skills, it is important to recognize and adapt to changes.
In the field survey, respondents revealed that they possessed the necessary skills to perform their work within the organization. The competency identified by respondents as most important was ease of relationship formation, which involves teamwork and partnership building. As one respondent stated:

"People need to demonstrate ease of relationship formation. You have to know how to communicate well, to translate technical language into a friendlier language. It is essential to have partnerships with other areas" (Technology manager).

The participants' responses indicate that communication is also a required competency, particularly for managers of large teams, such as those in the customer service, commercial and credit areas. Managers explained that it is important to know how to communicate with different audiences and to use language that is appropriate for each audience. According to one respondent:

One type of language is used to report to a director, another is used to address a technical team and a third and very different type of language is used in a call center. When I came on board, I developed a motivational campaign that was based on the attendants' performance delta. It was a failure because they did not know what delta meant. (Customer service manager)

Systemic vision and logical reasoning were also mentioned by the respondents. These skills make it possible to understand various scenarios, analyze situations in a structured way, and make rational decisions that are consistent with the company's strategy. Such skills are essential for the boundaryless career because they allow the individual to migrate from one organization to another.

Know-Whom Competencies. Know-whom competencies refer to the network of relationships in an individual's professional life. Such competencies were addressed in the interviews. Respondents recognized the role of interpersonal relationships in their career. The social networks that they establish in the working environment, professional courses or any other situations that allow the exchange of professional experiences 
increase the likelihood that new employment opportunities will arise in the future. The importance of relationship networks became clear during the interviews. However, certain respondents perceived a distinction between their own relationship networks and those of the organization in which they work. Indeed, this distinction is described in the scientific literature (e.g., Lacombe, 2005). As one respondent said:

The bank name is fantastic. When I say that I work here, it makes a big impression on people. In contrast, my name is unique in the market. I have one opportunity to introduce myself and I cannot waste it. The bank opens doors for me and I have the responsibility to do the right thing. So I maintain good relationships with judges and chief justices. (Legal manager)

However, although interpersonal relationships are important factors in participants' careers and managers recognize the opportunities generated by relationship networks, efforts to maintain such networks are less apparent. The analysis of the interviews indicates that employment shifts typically occur at the invitation of former managers, although meetings dedicated to the exchange of information and experience and the development of individuals' own relationships networks also occur, albeit rarely.

Responsibility for the Career. In recent years, the premise that the individual is responsible for his own career has been widely and persistently disseminated in many large companies, including the studied financial institution. Significantly, $64 \%$ of the respondents believe that they are responsible for their own careers. These respondents maintain that it is the duty of each individual to analyze their work satisfaction and - if it is found lacking - to leave and find another job that brings personal fulfillment. According to one respondent:

I think everyone is responsible for their own career. Ultimately, if I am not happy or am not receiving returns or recognition, I will look elsewhere. If I stay, I stay because I want to; if I leave, I leave because I want to. (Legal manager)
Another respondent added:

The institution is much larger than the individual and it cannot make decisions for each individual. The individual has the capacity to make decisions for himself, and this helps him to reconcile his career with what actually makes him happy. When a person truly assumes responsibility for his own career management, he stops justifying things and blaming others. (Credit and collections superintendent)

However, although many respondents argue that the individual is responsible for his own career, only two respondents seem to have effectively assumed that responsibility. At the beginning of their professional lives, these two respondents defined career stages and final goals, and today, they monitor their progress in a structured and consistent way.

In contrast, $36 \%$ of respondents identified other factors that influence the development of an individual's career. For example, certain respondents believe that the organization has partial responsibility for the individual's career because the organization can provide the employee with a challenging environment in which he can develop professionally. These respondents also consider the organization accountable for evaluating the conditions necessary for the professional to achieve his goals and for advising the individual of suitable career paths.

\section{Discussion}

In this section, emphasis is given to three issues that emerged from the results of the field research. The first issue is the apparent paradox between the strong presence of boundaryless career attitudes and respondents' employment in a traditional organization. The second issue refers to the differences between organizational areas. Finally, the third issue relates to the relationship between duration of employment at the company and boundaryless career attitudes. These three issues reflect the central objectives of this investigation.

The results of both stages of the present study indicate that respondents possess bound- 
aryless career attitudes. However, these professionals work for a traditional organization, which is characterized by a rigid hierarchy and obstacles to mobility. Thus, although the managers appear to have boundaryless career attitudes, they nonetheless seem to accept the standards of a traditional organizational career. How can this paradox be explained?

A previous reflection on this apparent paradox can be found within the conclusions of the study by Gerber et al. (2009). These authors note that "new" career orientations can coexist with "old" orientations; that is, there is not a clear separation between these models in terms of values and daily practices. First, despite the much vaunted changes in the working world, there are still zones of provisional stability, including the studied organization, where $63 \%$ of the professionals included in the study have between 10 and over 20 years of "traditional" employment.

Moreover, as noted by Veloso and Dutra (2011) with regard to boundaryless career experiences in a bank, psychological factors appear more important than the physical mobility factor, which seems to explain the difference between an attitude that aligns more closely to the traditional concept of organizational career (e.g., continuing employment at a single organization throughout one's professional career and the belief that career decisions are centered in the organization) and a boundaryless career attitude (e.g., mobility and taking responsibility for one's own professional development; Tams \& Arthur, 2010). At first glance, therefore, the apparent paradox may be superficial in nature because the different career orientations do not seem incompatible. The paradox may ultimately exist between agency and structure, as discussed in the current lines of research in the field of career studies and as mentioned in the introduction (Peiperl \& Arthur, 2000).

A second reflection on the apparent paradox may be found in the findings of another study presented in the introduction, which also considers the banking sector. In this study, Oltramari and Lorenzato (2012) emphasize that a possible "frontier" for boundaryless careers of bank managers is the family. Although the quantitative analysis undertaken here does not reveal significant differences based on whether the professional was married and/or had children, it can be argued that these factors may to some extent favor maintenance of the bond with the organization notwithstanding a strong tendency toward boundaryless career attitudes. It is possible that significant relationships were not identified because a majority of the sample $(82 \%)$ is married and a majority $(68 \%)$ has children. Given the corroborative findings in the literature that highlight the contextual constraints of a boundaryless career (Dany, 2003; Duberley, Mallon, \& Cohen, 2006), one might conclude that the organization offers certain opportunities to its professionals (including intra-organizational mobility) because of its position in the market.

Therefore, it is possible to consider the aforementioned paradox in terms of the psychological contract between the professional and the organization (Rousseau, 1995). The evidence gathered here supports the notion that professionals recognize a mutually beneficial transaction between each of them and the organization. Professionals analyze proposed alternatives, exchanges and choices to make decisions regarding their careers. The organization, which is aware that differentiated rewards contribute to a stronger bond between the employee and the company, creates mechanisms to ensure the retention of professionals. A significant example of such a mechanism is the subsidization of graduate courses for employees. After completion of the course, the employee is subject to a grace period during which he may not leave the company. Such a system allows the individual to develop transportable skills but also forces him to accept a mandated bond with the organization for the length of the grace period. This and many other mechanisms allow the presence of boundaryless career attitudes in a traditional organization.

Regarding the differences between areas, the quantitative stage yielded several important results. For example, the technology area achieved a significantly higher mean in the BCAS when compared to two other areas (credit and collections and human resources). 
In the qualitative stage, respondents in the technology area displayed detachment from the organization, stating that they will remain with the organization so long as they agree "with the culture", with the direction of the business and with the psychological contract between the company and its employees. Thus, in this regard, the qualitative results are consistent with the quantitative results.

These results are consistent with a broader trend involving professions in the information and communication technology field (Allvin, 2011; Saxenian, 1996). Specifically, these technologies have achieved prominence and strategic value for companies. They are based on expert, often hermetic, knowledge that is dominated by specific groups of professionals who develop easily transportable skills, maintain external relationship networks and have high employability and mobility (Lopes \& Silva, 2009). These characteristics shape a professional culture that favors boundaryless career attitudes, even among employees who work within large companies, as in the case of the studied organization.

However, it must be emphasized that the effect size of the aforementioned differences in means between areas was small; that is, although these differences are significant, they may not have a significant practical meaning. Nevertheless, the mere existence of these differences, albeit small, suggests the occurrence of the phenomenon noted in the introduction, namely, the plausible existence of a borderless career within a large organization, despite the dilemmas that arise from this phenomenon, as suggested by Oltramari and Lorenzato (2012).

Finally, the quantitative stage of the research revealed a greater propensity of boundaryless career attitudes among professionals with shorter tenures at the company. Naturally, this condition of shorter tenures at the company is also associated with the ages of the professionals, which leads to the hypothesis that younger professionals tend to exhibit stronger boundaryless career attitudes compared with older professionals. This hypothesis is consistent with findings in the literature (e.g., Currie et al.,
2006). In addition, contextual factors may help explain this result. First, young people may have attributes (e.g., being single) that provide more favorable conditions for mobility (physical and psychological); second, young people may be more open to exploratory career attitudes (Super, Savickas, \& Super, 1996), which implies a greater willingness to be mobile. These factors may have implications for the management systems of organizations, as explained further in the following section.

\section{Conclusion}

The objective of the present study was to apply the boundaryless career model to analyze the attitudes of individuals towards their careers in a large Brazilian financial institution. Methodologically, a mixed design was used (quantitative and qualitative). Based on the field research, it was possible to identify boundaryless career attitudes in employees of the studied organization.

The trend towards boundaryless careers can be observed in the interview responses, which identify know-why, know-how and know-whom competencies. Respondents exhibited developed know-why competencies by showing an understanding of their interests and motivations. Moreover, respondents seem to invest in know-how competencies, indicating a knowledge of which skills are required to develop professionally. Such skills - including partnership building, negotiation, people management, communication and leadership can be considered transportable, that is, they may be used in other organizations. Finally, regarding know-whom competencies, although managers recognize the opportunities created by relationship networks based on their own experiences, few seem to be willing to invest the time to build and maintain such networks.

One explanation for the development of boundaryless career attitudes seems to be related to the search for meaning at work. In the interviews, interviewees indicated that they had autonomy and the freedom to decide which factors would give meaning to their work. These 
characteristics are present in the literature on the meaning of work and in the literature on boundaryless careers (Lips-Wiersma \& Mcmorland, 2006; Meaning of Work International Research Team [MOW], 1987).

Paradoxically, although the general trend points towards boundaryless career attitudes, many respondents have maintained strong ties with the organization, guiding their careers in accordance with the opportunities offered by the company. These respondents understand progress as ascending the ranks of the organization and attribute the evolution or stagnation of their careers to chance. Thus, although individuals expressed boundaryless career attitudes, it cannot be said that this expression corresponds to an "ideal" boundaryless career. The present study seems to reveal a hybrid situation characterized by the coexistence of different attitudes towards careers. The evidence indicates different levels of boundaryless career attitudes among respondents and among areas.

Note that the present study was conducted in an exploratory manner. It is believed to contribute to the advancement of careers studies in Brazil because it portrays and analyzes the attitudes of managers in a large local organization toward boundaryless careers. However, the study has certain limitations that provide opportunities for future research. The first limitation is that the research was conducted in a single large organization. The second limitation is that the study was limited to leaders. It would be helpful to expand the research to other professional strata within the organization. In addition, it would be useful to conduct research that could deepen the understanding of the three issues addressed in the previous section: the strong presence of boundaryless career attitudes in a traditional organization; the differences between areas; and the relationship between tenure at the company and boundaryless career attitudes. Such questions may be of interest to researchers in the career and human resources fields who are interested in achieving a better understanding of the ongoing transition process.

The present study makes three practical contributions. First, this study reveals that the organizational coexistence of professionals and groups with differentlevels ofboundaryless career attitudes generates tensions. These tensions stem from different perspectives and expectations regarding development, professional growth and mobility. This tension should be addressed by managers. Second, the survey reveals that professionals who have more interaction with the labor market and with colleagues from other companies (as in the case of professionals in the technology area) have higher levels of boundaryless career attitudes. This relation should also be addressed by managers. Third, the results reveal the complexity and certain paradoxes related to boundaryless careers. Understanding these aspects of boundaryless careers is essential for managers in general and for human resource managers in particular. The reality of boundaryless careers has relevant implications for the relationships between professionals and companies.

\section{References}

Allvin, M. (2011). New rule of work: Exploring the boundaryless job. In K. Naswall, J. Hellgren, \& M. Sverke (Eds.), The individual in the changing working life (pp. 19-45). Cambridge, UK: Cambridge University Press.

Arthur, M. B. (1994). The boundaryless career: A new perspective for organizational inquiry. Journal of Organizational Behavior, 15(4), 295306. doi:10.1002/job

Arthur, M. B., Hall, D. T., \& Lawrence, B. S. (1989). The handbook of career theory. Cambridge, UK: Cambridge University Press.

Arthur, M., Inkson, K., \& Pringle, J. K. (1999). The new careers. Thousand Oaks, CA: Sage.

Arthur, M. B., \& Rousseau, D. M. (1996). The boundaryless career: New employment principle for a new organizational era. Oxford, UK: Oxford University Press.

Balassiano, M. (2006). Gestão de carreiras: Dilemas e perspectivas. São Paulo, SP: Atlas.

Bardin, L. (1977). Análise de conteúdo. Lisboa, Portugal: Edições 70.

Baruch, Y. (2004). Transforming careers: From linear to multidirectional careers paths. $\mathrm{Ca}$ - 
reer Development International, 9(1), 58-73. doi:10.1108/13620430410518147

Baruch, Y. (2006). Career development in organizations and beyond. Human Resource Management Review, 16(2), 125-138. doi:10.1016/j. hrmr.2006.03.002

Bastos, V. B., \& Andrade, A. E. (2002). Comprometimento com o trabalho: Padrões em diferentes contextos organizacionais. Revista de Administração de Empresas, 42(2), 31-41. doi:10.1590/ S0034-75902002000200003

Beck, U. (2000). The brave new world of work. London: Polity.

Bendassolli, P. (2009). Recomposição da relação sujeito-trabalho nos modelos emergentes de carreira. Revista de Administração de Empresas, 49(4), 387-400. doi:10.1590/S003475902009000400003

Bendassolli, P. F., \& Wood, T., Jr. (2010). O paradoxo de Mozart: Carreiras nas indústrias criativas. Organizações \& Sociedade, 17, 259-277. doi:10.1590/S1984-92302010000200002

Borgen, W. A., Amundson, N. E., \& Reuter, J. (2004). Using portfolios to enhance career resilience. Journal of Employment Counseling, 41(2), 5059. doi:10.1002/j.2161-1920.2004.tb00878.x

Briscoe, J., Hall, D., \& DeMuth, R. (2006). Protean and boundaryless careers: An empirical exploration. Journal of Vocational Behavior, 69, 30-47. doi:10.1016/j.jvb.2005.09.003

Chanlat, J. F. (1995). Quais carreiras e para qual sociedade? Revista de Administração de Empresas, 35(6), 67-75. doi:10.1590/S003475901995000600008

Colakoglu, S. N. (2011). The impact of career boundarylessness on subjective career success: The role of career competencies, career autonomy, and career insecurity. Journal of $\mathrm{Vo}$ cational Behavior, 79(1), 47-59. doi:10.1016/j. jvb.2010.09.011

Currie, G., Tempest, S., \& Starkey, K. (2006). New careers for old? Organizational and individual responses to changing boundaries. International Journal of Human Resource Management, 17(4), 755-774. doi:10.1080/09585190600581733

Dany, F. (2003). Free agents and organizations. International Journal of Human Resource Management, 14(5), 821-838.
DeFillippi, J. R., \& Arthur, M. B. (1994). The boundaryless career: A competency-based perspective. Journal of Organizational Behavior, 15(4), 30724. doi:10.1002/job.4030150403

Dubar, C., \& Tripier, P. (2005). Sociologie des professions. Paris: Armand Colin.

Duberley, J., Mallon, M., \& Cohen, L. (2006). Exploring career transitions: Accounting for structure and agency. Personnel Review, 35(3), 281296. doi:10.1108/00483480610656694

Dutra, J. S. (2009). Gestão de carreiras na empresa contemporânea. São Paulo, SP: Atlas.

Eby, L. T., Butts, M., \& Lockwood, A. (2003). Predictors of success in the era of the boundaryless career. Journal of Organizational Behavior, 24, 689-708.

Fontenelle, I. (2007). A autogestão de carreira chega à escola de administração: $\mathrm{O}$ humano se tornou capital? Organizações \& Sociedade, 14(43), 7189. doi:10.1590/S1984-92302007000400004

Forret, M. L., Sullivan, S. E., \& Mainiero, L. A. (2010). Gender role differences in reactions to unemployment: Exploring psychological mobility and boundaryless careers. Journal of Organizational Behavior, 31, 647-666. 10.1002/ job.703

Gerber, M., Wittekind, A., Grote, G., Conway, N., \& Guest, D. (2009). Generalizability of career orientations: A comparative study in Switzerland and Great Britain. Journal of Occupational and Organizational Psychology, 82(4), 779-801. doi:10.1348/096317909X474740

Grzeda, M. M. (1999). Re-conceptualizing career change: A career development perspective. $\mathrm{Ca}$ reer Development International, 4(6), 305-311. doi:10.1108/13620439910287979

Gunz, H., \& Peiperl, M. (2007). Handbook of career studies. London: Sage.

Hall, D. T. (1976). Career in organizations. Glenview, IL: Scott Foresman.

Hall, D. T. (2002). Careers in and out of organizations. Thousand Oaks, CA: Sage.

Hall, D. T. (2004). The protean career: A quartercentury journey. Journal of Vocational Behavior, 65(1), 1-13. doi:10.1016/j.jvb.2003.10.006

Inkson, K. (2007). Understanding careers. London: Sage. 
Inkson, K., \& Baruch, Y. (2009). Organizational careers. In S. R. Clegg \& C. L. Cooper (Eds.), The Sage handbook of organizational behavior ( $\mathrm{pp}$. 209-223). Thousand Oaks, CA: Sage.

Inkson, K., \& Parker, P. (2005). Boundaryless career and the transfer of knowledge: A "Middle Earth" perspective. Higher Education Police, 18, 313-325. doi:10.1057/palgrave.hep.8300093

Kilimnik, Z. M. (Ed.). (2011). Transformações e transições nas carreiras. Rio de Janeiro, RJ: Qualitymark.

Kilimnik, Z. M., Sant'Anna, A. S., \& Castilho, I. V. (2007). Carreiras em transformação e seus paradoxais reflexos nos indivíduos. In D. T. R. Barros, M. T. Lima, \& R. Escalda (Eds.), Escolha e inserção profissionais (pp. 21-42). São Paulo, SP: Vetor.

Lacombe, B. (2005). O modelo da carreira sem fronteiras no contexto organizacional: Pesquisando a carreira do professor universitário no Brasil (Relatório No. 08). Brasília, DF: Fundação Getúlio Vargas.

Lips-Wiersma, M. S., \& Mcmorland, J. (2006). Finding meaning and purpose in boundaryless careers. Journal of Humanistic Psychology, 46(2), 147-167. doi:10.1177/0022167805283776

London, M., \& Bray, D. W. (1984). Measuring and developing young manager's career motivation. Journal of Management Development, 3(3), 3-25.

Lopes, A. L., \& Silva, J. R. (2009). Expectativas profissionais no discurso de terceirizados em TI. Revista de Administração Eletrônica, 8(2), 1-24. doi:10.1590/S1676-56482009000200002

McMahon, M. L., \& Patton, W. A. (2006). Career counselling: Constructivist approaches. London: Routledege.

Meaning of Work International Research Team. (1987). The meaning of working. New York: Academic Press.

Mendenhall, M. E., Kuhlmann, T. M., \& Stahl, G. K. (2001). Developing global business leaders: Policies, processes and innovations. New York: Quorum Books.

National Health Council. (1996). Diretrizes e normas regulamentadoras de pesquisas envolvendo seres humanos: Resolução Nº196/96. Retrieved from http://pfdc.pgr.mpf.mp.br/atuacao-e-conteudos-de-apoio/legislacao/saude/resolucoes/ Resolucao_CNS_196.1996

Oliveira, M., Zanon, C., Silva, I., Pinhatti, M., Gomes, W., \& Gauer, G. (2010). Validação da versão brasileira da Escala de Atitudes de Carreiras Sem Fronteiras. Arquivos Brasileiros de Psicologia, 62(3), 106-114.

Oltramari, A., \& Lorenzato, S. (2012). Dilemas da carreira sem fronteira: Um estudo de caso com gerentes bancários. Revista de Carreiras e Pessoas, 2(3), 2-19.

Peiperl, M. A., \& Arthur, M. B. (2000). Topics for conversation: Career themes old and news. In M. A. Peiperl, M. B. Arthur, R. Goffee, \& T. Morris (Eds.), Career frontiers: New conceptions of working lives (pp. 1-20). Oxford, UK: Oxford University Press.

Pringle, J. K., \& Mallon, M. (2003). Challenges for the boundaryless career odyssey. International Journal of Human Resource Management, 14(5), 839-853.

Rousseau, D. (1995). Psychological contracts in organizations. London: Sage.

Savickas, M. (2009). Revitalising vocational psychology and energising the study of career: A way forward. In A. Collin \& W. Patton (Eds.), Vocational psychological and organizational perspectives on career (pp. 197-208). Rotterdam, Holland: Sense.

Saxenian, A. L. (1996). Beyond boundaries: Open labor markets and learning in Silicon Valley. In M. Arthur \& D. M. Rousseau (Eds.), The boundaryless career (pp. 23-39). New York: Oxford University Press.

Scalabrin, A. C. (2008). Carreiras sem fronteiras e trajetórias descontínuas: Um estudo descritivo sobre decisões de opt-out (Dissertação de mestrado, Faculdade de Economia, Administração e Contabilidade, Universidade de São Paulo, SP, Brasil).

Stickland, R. (1996). Career self-management. International Journal of Work and Organizational Psychology, 5(4), 583-596.

Sullivan, S. E. (1999). The changing nature of careers: A review and research agenda. Journal of Management, 25(3), 457-484. doi:10.1177/014920639902500308 
Super, D. E., Savickas, M. L., \& Super, C. M. (1996). The life-span, life-space approach to careers. In D. Brown \& L. Brooks (Eds.), Career choice and development (pp. 121-178). San Francisco, CA: Jossey-Bass.

Tams, S., \& Arthur, M. (2010). New directions for boundaryless careers: Agency and interdepence in a changing world. Journal of Organizational Behavior, 31, 629-646. doi:10.1002/job.712

Templer, A. J., \& Cawsey, T. F. (1999). Rethinking career development in an era of portfolio careers. Career Development International, 2(2), 70-76. doi:10.1108/13620439910254669

Van Maanen, J. (1977). Organizational careers: Some new perspectives. New York: John Wiley \& Sons.
Veloso, E., \& Dutra, J. (2011). Carreiras sem fronteiras na gestão pessoal da transição profissional: Um estudo com ex-funcionários de uma instituição privatizada. Revista de Administração Contemporânea, 15(5), 834-854. doi:10.1590/S1415-65552011000500004

Recebido: $15 / 08 / 2014$

$1^{a}$ revisão: $18 / 12 / 2014$

$2^{a}$ revisão: $13 / 03 / 2015$ Aceite final: 18/03/2015 